\title{
LITURGHIE ŞI FILANTROPIE, DIMENSIUNI PASTORAL - MISONARE ALE BISERICII
}

Marian VÎLCIU*

\begin{abstract}
The Divine Liturgy represents the heart and the essence of the Orthodox public divine service, being, at the same time, also the fundamental service of the communion between man and God, but also among men. The Orthodox Church is, par excellence, a liturgical Church, its service, at the center of which there is the Divine Liturgy, representing precisely the life of the Church and equally the accurate expression of the teaching of faith. In this context, the Divine Liturgy is the work of the people for God, and also the work-response of God for men. Yet, we need to underline the fact that the Mystery of the Altar, namely the Divine Eucharist, being the core of the Divine Liturgy, is never authentically fruitful without the Mystery of brotherhood, in other words, without serving our fellows, which turns the philanthropic work of the Church for man and for the world into something by which the Liturgy is continued outside the Church. Consequently, we can talk about "the Liturgy after the Liturgy", both of them being pastoral missionary dimensions of the Church.
\end{abstract}

Keywords: Church, Divine Liturgy, Divine Eucharist, service, fellow, philanthropy, salvation.

Biserica Ortodoxă se caracterizează, printre altele, prin cultul său de o deosebită frumusețe şi profunzime teologică. Definit ca totalitate a actelor menite să îl pună pe om în legătură cu Dumnezeu',

* $\mathrm{PhD}$, Associate Professor, Dean, Faculty of Theology, Valahia University, Târgoviş̧te, Romania.

${ }^{1}$ Ene Branişte, Liturgica Generală, București, Editura Institutului Biblic și de Misiune al Bisericii Ortodoxe (în continuare, EIBMBOR), 1993, p. 45. 
cultul divin public ortodox prin bogăția doctrinară, prin frumusețea formelor şi a actelor de cult, prin semnificația simbolică deosebită, reuşeşte să întrețină legătura dintre credincioşi şi Dumnezeu făcând posibilă revărsarea de binecuvântare şi har peste cei care alcătuiesc Biserica Mântuitorului Hristos.

În centrul cultului divin public ortodox stă Sfânta şi Dumnezeiasca Liturghie, pe care teologia ortodoxă o numeşte, întru totul justificat, de altfel, centrul şi esența cultului ortodox. Deşi cultul ortodox este alcătuit din numeroase alte slujbe bisericeşti, trebuie să spunem că nici una dintre acestea nu egalează importanţa şi semnificația teologică şi eclezială a Sfintei Liturghii. Centralitatea ei este subliniată şi de faptul că în jurul ei gravitează toate celelalte slujbe ale cultului divin public ortodox, semn că toate acestea îşi întemeiază puterea şi lucrarea lor sfințitoare pe jertfa Mântuitorului Hristos, jertfă care este actualizată de fiecare dată în Sfânta Liturghie. Astfel, unele slujbe fac parte integrantă din rânduiala Sfintei Liturghii, cum este cazul Sfintei Împărtăşanii, al Tainei Preoției, Sfinţirea Sfântului şi Marelui Mir, Sfințirea Antimiselor ${ }^{2}$ sau Sfințirea cea mare a Apei ${ }^{3}$. Alte slujbe preced rânduiala Sfintei Liturghii, cum este cazul marii majorităţi a Laudelor bisericeşti, al hirotesiilor, al Slujbei de sfinţire a Bisericii sau al Tainei Botezului şi Mirungerii, cum se săvârşeau la începuturile Bisericii creştine ${ }^{4}$. O altă parte a slujbelor bisericeşti urmează Sfintei Liturghii: Taina Nunții, slujbele funebre, de pomenire a celor adormiții, unele Laude bisericeşti etc.

Este îndeobşte cunoscut faptul că unul dintre scopurile cultului divin public ortodox este scopul latreutic, adică acela care se referă la adorarea lui Dumnezeu şi prin care se exprimă sentimentele noastre de evlavie, de respect, de recunoştință, de admirație şi de dragoste față de Însuşi Dumnezeu. Altfel spus, prin funcția latreutică a cultului se are în vedere totalitatea actelor religioase prin care

\footnotetext{
${ }^{2}$ Vezi Arhieraticon, București, EIBMBOR, 1993, pp. 73, 119, 191 ș.u.

${ }^{3}$ Vezi Molitfelnic, București, EIBMBOR, 1998, p. 575 ș. u.

${ }^{4}$ Pentru amănunte vezi Nenad S. Miloșevici, Dumnezeiasca Liturghie - centrul cultului in Ortodoxie, Sibiu, Editura Deisis, 2012, p. 19 ş.u.
} 
credinciosul îşi exteriorizează nevoia firească de a preamări pe Dumnezeu şi de a cinsti pe Sfinți, exteriorizare care se realizează prin diferite forme de exprimare, forme care țin de rugăciunea de laudă (Laudele bisericeşti), rugăciunea de cerere (Taine şi Ierurgii) şi rugăciunea de mulțumire (în special Sfânta Liturghie prin Taina Împărtăşirii sau a Euharistiei, care înseamnă mulțumire).

Superioritatea Sfinte Liturghii față de toate celelalte slujbe ale cultului ortodox este subliniată şi de faptul că ea, Liturghia, reprezintă suprema formă de adorare a lui Dumnezeu. Fiind instituită direct de Însuşi Mântuitorul Hristos la Cina cea de Taină, Sfânta Liturghie este singura slujbă de origine divină $\breve{s}^{5}$. Fiind instituite de Biserică, Laudele Bisericeşti care premerg Sfânta Liturghie sunt considerate ca fiind, într-un anume fel, o introducere a acesteia. În cadrul lor, Biserica aduce lui Dumnezeu mai ales rugăciune, fie de laudă, fie de cerere, fie de mulțumire, însă, prin slujba Sfintei Liturghii Biserica aduce lui Dumnezeu cu mult mai mult, adică jertfă, forma cea mai aleasă prin care se exprimă cultul de adorație care se cuvine numai lui Dumnezeu. În Liturghie, Hristos Însuşi jertfeşte şi Se jertfeşte pentru noi şi în legătură de unire cu noi, după cum Însuşi mărturiseşte ,Şi pentru ei Mă sfințesc şi pe Mine Însumi, ca şi ei să fie sfințiți în adevăr" (Ioan 17, 19). Astfel, jertfa liturgică care se săvârşeşte în cadrul Sfintei Liturghii este cea mai înaltă jertfă de laudă, de mulțumire, de cerere sau mijlocire, dar şi de ispăşire şi de împăcare pe care credincioşii o pot aduce lui Dumnezeu. Aşadar, putem spune că Sfânta Liturghie este sublimul imn de laudă şi de slavă pe care Biserica îl aduce lui Dumnezeu pentru puterea, majestatea şi perfecțiunile Sale. Mântuitorul Hristos, Care se întrupează „pentru noi oamenii şi pentru a noastră mântuire”, îşi desfăşoară activitatea Sa mântuitoare pentru lume şi pentru om, slăvind în acelaşi timp pe Dumnezeu Tatăl: „Eu Te-am proslăvit pe Tine pe pământ " (Ioan 17, 4).

${ }^{5}$ Ene Branişte, Liturgica Specială, Bucureşti, EIBMBOR, 1980, p. 294. 
Însă, Liturghia este nu numai suprema formă prin care se înfăptuieşte cultul de adorare a lui Dumnezeu, ci ea este şi suprema formă prin care se exprimă cultul de cinstire sau de venerare, căci în Sfânta Liturghie cinstim nu doar pe Dumnezeu, ci şi pe sfinţi. Este adevărat că jertfa liturgică se aduce numai lui Dumnezeu, însă, ea se aduce şi spre „cinstea şi pomenirea sfinților”, cinste care se aduce de fapt tot lui Dumnezeu, drept mulțumire, Cel care a revărsat din darurile Sale peste oameni, peste sfinți, prietenii Săi. Lucrul acesta este arătat lămurit de Sfinții Părinți ai Bisericii: „Darurile sunt întradevăr ale lui Dumnezeu, ca unele ce sunt ale Lui; ele sunt şi ale credincioşilor care au nevoie de ajutor, ca unele ce sunt ajutătoare; dar totodată sunt şi ale Sfinţilor, deoarece sunt aduse lui Dumnezeu din pricina lor" ${ }^{\prime \prime}$.

Sfânta Liturghie este în acelaşi timp expresia desăvârşită a sentimentelor noastre de recunoştință şi de mulțumire faţă de Dumnezeu pentru darurile şi binefacerile primite cu prisosință de la El. Pentru aceasta, ceea ce este, de fapt, centrul Liturghiei, Taina Împărtăşaniei, poartă numele de Euharistie, adică mulţumire, funcția euharistică a Liturghiei fiind subliniată şi de numeroase alcătuiri imnografice ale Liturghiei: „Să mulțumim Domnului”; , Pe Tine Te lăudăm, Pe Tine Te binecuvântăm, Ție Îți mulțumim Doamne..."7.

Sfânta Liturghie este, de asemenea, slujba în care, prin jertfa liturgică ce se săvârşeşte în cadrul ei, se înfăptuieşte împăcarea cu Dumnezeu, jertfa liturgică fiind jertfă care se aduce lui Dumnezeu pentru iertarea păcatelor noastre, fapt subliniat chiar de formula Liturghiei care se rosteşte la împărtăşirea credincioşilor: „Se împărtăşeşte robul lui Dumnezeu (N), cu Cinstitul şi Sfântul Sânge al Domnului şi Dumnezeului şi Mântuitorului nostru Iisus Hristos, spre iertarea păcatelor şi spre viaţa de veci "

$\mathrm{Nu}$ în ultimul rând, Sfânta Liturghie este cea mai folositoare rugăciune de cerere sau de mijlocire din cultul Bisericii, prin care

${ }^{6}$ Nicolae Cabasila, Tâlcuirea Dumnezeieştii Liturghii şi Despre viața $\hat{\imath}$ Hristos, București, Editura Arhiepiscopiei Bucureștilor, 1989, p. 100.

${ }^{7}$ Liturghier, Bucureşti, EIBMBOR, 2000, pp. 160, 163.

${ }^{8}$ Ibidem, p. 182. 
credincioşii imploră pe Dumnezeu să le dăruiască iertare de păcate şi mântuire, lor şi celor dragi ai lor, vii sau adormiți, pentru care aduc daruri la Liturghie, aducerea de daruri fiind şi una din formele de participare a acestora la săvârşirea Sfintei Liturghii ${ }^{9}$. Aşadar, jertfa liturgică se aduce atât pentru cei vii, cât şi pentru cei adormiţi, Liturghia fiind „mijlocul cel mai bun pe care-l avem la îndemână, pentru a mijloci uşurarea de păcate, mângâiere şi odihnă răposaților noştri" ${ }^{10}$. De aceea, slujbele de pomenire pentru cei adormiţi se săvârşesc de către Biserică în strânsă legătură cu Sfânta Liturghie. Astfel, Sfânta Liturghie întreține legătura de dragoste care uneşte pe cei vii cu cei adormiţi şi cu toți sfinții, toți alcătuind, de fapt, un singur trup, trupul tainic al lui Hristos, Biserica.

Liturghia reprezintă, aşadar, slujba cea mai însemnată din cultul Bisericii Ortodoxe prin care se lucrează mântuirea noastră: „Căci nu există o altă formă de rugăciune care să poată atât de mult şi care să ne dea nădejdi mai tari ca aceea adusă prin această înfricoşătoare Jertfă, care a curățit fără nici o plată, păcatele şi fărădelegile lumii"11.

După cum în centrul activităţii răscumpărătoare a Mântuitorului Hristos stau patimile, jertfa de pe cruce, moartea şi învierea Sa din morţi, tot aşa şi Sfânta Liturghie, care reînnoieşte şi reactualizează această jertfă în Biserică până la sfârşitul veacurilor, este cea care deține locul central, este coroana tuturor celorlalte slujbe care alcătuiesc cultul Bisericii Ortodoxe, fiind în acelaşi timp cea mai veche slujbă a cultului creştin.

Sfânta Liturghie este slujba dumnezeiască în care se aduce jertfa cultului Legii celei noi, cult instituit de Mântuitorul Hristos, este „taina curăţirii, sfinţirii, luminării, renaşterii, facerii omului pentru viața veşnică; taina iubirii dumnezeieşti, taina înălțării,

\footnotetext{
${ }^{9}$ Ene Branişte, Liturgica Generală..., p. 113.

${ }^{10}$ Idem, Liturgica Specială..., p. 297.

${ }^{11}$ Nicolae Cabasila, op. cit., p. 64.
} 
îndumnezeirea omului lipsit de ajutor"12, taina prin excelență a comuniunii.

Liturghia reprezintă prin urmare, centrul cultului Bisericii Ortodoxe. De altfel, Biserica Ortodoxă mărturiseşte că jertfa euharistică, pe care comunitatea credincioşilor o aduce lui Dumnezeu prin sfințiţii slujitori, potrivit mandatului pe care Mântuitorul Hristos 1-a dat Sfinţilor Apostoli şi, prin ei, episcopilor şi preoților: „Aceasta să faceți întru pomenirea Mea " (Luca 22, 19), reprezintă neîndoielnic, esența şi punctul culminant al Sfintei Liturghii şi fundament la unităţii Bisericii ${ }^{13}$.

Ținând seama de înţelesul ei profund teologic şi mistic, Sfânta Liturghie este, în egală măsură, o lucrare de mulțumire sau de manifestare a recunoştinței poporului credincios

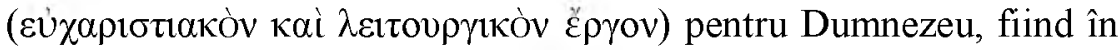
acelaşi timp, lucrare sfinţitoare a lui Dumnezeu pentru poporul Său. Prin Liturghie, se manifestă şi se confirmă prezența şi lucrarea lui Dumnezeu în mijlocul poporului credincios, în Biserica. Liturghia ortodoxă este, în primul rând, lucrarea de recunoştință, de mulțumire, pe care poporul lui Dumnezeu o aduce Celui ce a făcut cerul şi pământul pentru iubirea Sa faţă de oameni. Întruparea Mântuitorului Hristos, potrivit referatului biblic, fiind dovada supremei iubiri a lui Dumnezeu pentru lume, ,,atât de mult a iubit Dumnezeu lumea, încât a dat pe Fiul Său Cel Unul-Născut, ca oricine crede în El să nu piară, ci să aibă viață veşnică" (Ioan 3,16), este exprimată în Liturghie, care cuprinde frumusețea şi lucrarea filantropiei divine a Sfintei Treimi, descoperită şi împărtăşită lumii prin Iisus Hristos. Toate acestea ne arată în mod limpede şi fără echivoc că Sfânta Liturghie reprezintă mijlocul fundamental prin care se realizează în modul cel mai deplin comuniunea omului cu Dumnezeu şi cu aproapele său,

\footnotetext{
${ }^{12}$ Ioan din Kronștadt, Liturghia - cerul pe pământ, Sibiu, Edit. Deisis, 2002, p. 171.

${ }^{13}$ Gheorghios D. Mettalinos, Parohia - Hristos în mijlocul nostru, Sibiu, Edit. Deisis, 2004, p. 14.
} 
fiind, în acelaşi timp, şi slujba cu cel mai semnificativ rol pastoral şi duhovnicesc.

Creștinismul este supranumit religia iubirii, de aceea, putem spune că iubirea lui Hristos față de oameni şi a oamenilor faţă de Hristos reprezintă însăşi viața Bisericii. Istoria Bisericii creştine ne arată că între Liturghie şi filantropia socială a Bisericii există o legătură complementară şi de necesitate, una fiind interioară celeilalte $^{14}$. În acest sens, devine evident faptul că Dumnezeiasca Liturghie este slujba în care are loc celebrarea iubirii lui Dumnezeu față de lume, iar filantropia socială, adică lucrarea faptelor bune, este rodul binefăcător şi mântuitor al Sfintei Liturghii în viața lumii, fapt evidenţiat de Mântuitorul Hristos atunci când ne îndeamnă: „Aşa să lumineze lumina voastră înaintea oamenilor, ca văzând ei faptele voastre cele bune să preamărească pe Tatăl vostru Cel din ceruri" (Matei 5, 16). Potrivit acestui îndemn, Sfinții Apostoli şi, mai apoi, Sfinții Părinți ai Bisericii au unit frângerea pâinii, Liturghia, cu filantropia socială exprimată prin existența în cultul Bisericii primare a agapei frățeşti, precum şi cu organizarea de colecte, cu scopul de a ajuta pe cei săraci şi pe toți cei în nevoi, aşa cum lămurit putem înțelege din multiplele pasaje biblice din Faptele Apostolilor (2, 44$45 ; 4,34-35 ; 6,2-3 ; 14,17 ; 20,35)$ sau din unele scrieri ale Sfântului Apostol Pavel (I Corinteni 11, 20-21;16, 1-3; I Tesaloniceni 4, 9-12). Sfinții Părinți ai Bisericii au continuat practica apostolică a filantropiei sau a slujirii sociale, pe care o extind şi o organizează în instituții permanente, celebre şi reprezentative, fiind, din acest punct de vedere, instituțiile de caritate şi asistență socială întemeiate în secolul al IV-lea de Sfântul Vasile cel Mare († 379), autor al uneia dintre Liturghiile bizantine folosită şi, astăzi, în cultul Bisericii Ortodoxe. Sfântul Ioan Gura de Aur († 407), şi el autor al unei Liturghii, vorbeşte, cum numai el ar fi putut să o facă, despre Hristos Domnul Care în chip tainic este prezent în Euharistie, Taina

${ }^{14}$ A se vedea Pr. Prof. Dr. Valer Bel, Misiune, Parohie, Pastorație, Cluj, Edit. Renașterea, 2002, p. 121. 
Sfântului Altar, şi Care este la fel de prezent şi în Taina fratelui ${ }^{15}$, în slujirea aproapelui, a semenului nostru care are nevoie de ajutor.

Legătura de netăgăduit dintre Liturghie şi slujirea aproapelui este arătată de Mântuitorul Hristos Însuşi, Care, după ce săvârşeşte Cina cea de Taină şi instituie Taina Sfintei Euharistii, spală picioarele Apostolilor Săi, fapt care exprimă adevărul, potrivit căruia, roadele Liturghiei sunt binefăcătoare în viața celui credincios, numai în măsura în care acesta este condus în mod natural spre slujirea fratelui, a celui aflat în suferință şi care are nevoie de ajutor. Semnificativ în a înţelege legătura dintre taina fratelui şi misterul euharistic este episodul scripturistic în care se vorbeşte despre arătarea Mântuitorului Hristos, după înviere, celor doi ucenici ai Săi, pe drumul spre Emaus, Luca şi Cleopa, din care înțelegem că pentru a-L cunoaşte pe Dumnezeu trebuie să ne întâlnim cu El în Euharistie, întâlnire care se transformă în ospitalitate şi filantropie, Iisus Cel înviat din morți rămânând străin, ascuns şi necunoscut până în momentul în care are loc „frângerea pâinii”, într-o casă a ospitalitătii: „Iar odată primit, El conduce comuniunea inimilor şi viază tainic printre noi, devenind El Însuşi Viața vieții noastre"16. Descoperim, aşadar, că Taina fratelui sau slujirea filantropică a semenului nostru îşi are izvorul în taina Filantropiei divine, pe care Hristos Domnul, Fiul lui Dumnezeu, o descoperă atunci când Se întrupează din iubire pentru oameni şi pentru a lor mântuire. Astfel, aşa cum ne încredințează Sfântul Evanghelist Ioan, prin credința în Hristos, Fiul lui Dumnezeu întrupat, toți oamenii primesc puterea de a deveni fii ai lui Dumnezeu: „Şi celor câți L-au primit, care cred în numele Lui, lea dat putere ca să se facă fii ai lui Dumnezeu, care nu din sânge, nici din poftă trupească, nici din poftă bărbătească, ci de la Dumnezeu sau născut" (Ioan 1, 12-13), calitate care îi plasează într-o relaţie de iubire cu Dumnezeu Cel ce este Iubire, relație care face din ei un loc sacru al prezenței lui Hristos. Astfel, omul fiind cel în care

15 Daniel Ciobotea, Mitropolitul Moldovei, Taina fratelui, în „Candela Moldovei", III, nr. 1-2, p. 1 ş.u.

${ }^{16}$ Ibidem, p. 13. 
sălăşluieşte Hristos, devine persoană iubită de Dumnezeu Însuşi, prin urmare, întâlnirea cu Hristos în Taina Altarului sau a Sfintei Euharistii, nu trebuie niciodată despărțită de fapta bună şi milostivă îndreptată spre semenul nostru care devine taina fratelui sau a operă filantropică a Bisericii în lume.

Împărtăşirea cu Trupul şi Sângele lui Hristos, Cel răstignit şi înviat, nu trebuie înțeleasă numai ca un act personal, ca un exercițiu în sine, ci ca un îndemn spre comuniunea cu aproapele, aplecarea spre suferința acestuia, altfel spus, primirea Euharistiei trebuie să ne facă inima mai bună şi mai milostivă, devenind sensibili la suferințele semenilor noştri pentru care Hristos Domnul a murit şi a înviat. Spre o astfel de stare şi lucrare ne îndeamnă Sfântul Ioan Gura de Aur atunci când spune: „Vrei să cinstești Trupul Stăpânului? NuL disprețui, când este gol. Nu-L cinsti aici în Biserică cu haine de mătase (procovețele care acoperă Sfântul Disc şi Sfântul Potir la Liturghie) iar afară îl laşi să tremure de frig că n-are cu ce se îmbrăca! Cel ce a spus: Acesta este trupul Meu şi prin cuvânt a întărit lucrul, Acelaşi a spus şi «flămând $M$-aţi văzut şi $M$-aţi hrănit» şi «Întrucât n-ați făcut unuia dintre aceștia mai mici, nici Mie nu Mi-aţi făcut!»... Cinsteşte-L pe Hristos cu cinstea pe care El a poruncit-o, cheltuind cu săracii avuția ta: căci lui Dumnezeu nu-I trebuie potire de aur, ci suflete de aur"17.

Istoria Bisericii Ortodoxe ne înfățişează faptul că opera filantropică dezvoltată în Bizanț, cultivată de Sfinții Părinți ai Bisericii, care erau deopotrivă liturghisitori şi păstori, a fost una considerabilă, slujirea diaconală a aproapelui fiind strâns legată de săvârşirea Euharistiei. Această realitate a caracterizat lucrarea pastoral-misionară a Bisericii multă vreme, fenomen care a fost propriu şi Bisericii Ortodoxe din România, de-a lungul timpului, şi numai schimbările politice şi sociale mai recente au făcut ca aceasta să desfăşoare cu preponderență o activitate de tip liturgic. Astăzi, mai

${ }^{17}$ Sfântul Ioan Gură de Aur, Omilia 50 la Evanghelia după Matei, în PSB 23, București, EIBMBOR, 1994, p. 584. 
mult decât oricând, este nevoie ca Biserica să redescopere vocația ei liturgică-sacramentală şi diaconal-filantropică, dezvoltând o lucrare misionară integrală în care Liturghia este strâns unită cu filantropia, iar viața de rugăciune, izvor al sfințeniei şi al adevăratei iubiri, se împleteşte în mod armonios şi necesar cu slujirea aproapelui. Înțelegând necesitatea fundamentală a legăturii dintre Liturghie şi filantropie, ajungem la concluzia că „Liturghia eclesială inspiră filantropia socială creştină, iar Filantropia socială confirmă Liturghia ca fiind eveniment misionar de mărturisire a iubirii lui Dumnezeu pentru sfinţirea şi mântuirea oamenilor... Filantropia confirmă Liturghia când celebrarea liturgică inspiră comuniune şi coresponsabilitate misionară creştinilor activi în societate, sfințenia inspiră solidaritate cu cei singuri şi săraci, iar iertarea păcatelor primită în Biserică inspiră reconcilierea în societate. Astfel, viața spirituală din Biserică rodeşte în viața socială a creştinilor implicare activă pentru adevăr şi dreptate, pentru sănătate şi demnitate, pentru reconciliere şi solidaritate, în vederea mântuirii oamenilor prin har, credință şi fapte bune"18. Rezultă, aşadar, că Liturghia nu trebuie să se limiteze doar la slujba de celebrare în Biserică ${ }^{19}$, ci ea trebuie să se continue în viaţa credincioşilor, transformându-se în slujire diaconală, întâlnirea personală cu Hristos în Sfânta Euharistie devenind roditoare prin toată fapta cea bună, care se îndreaptă către aproapele nostru, Liturghia euharistică continuându-se, astfel, în liturghia fratelui.

În consecință, filantropia creștină, care izvorăște din Sfânta Liturghie înțeleasă ca realitate a prezenței iubirii milostive a lui Dumnezeu faţă de om, este o componentă importantă şi necesară a lucrării Bisericii şi un element obligatoriu al strategiei pastoralmisionare. $\mathrm{O}$ comunitate parohială autentic creştină trebuie să se manifeste ca o comunitate de mărturisire a adevărului Evangheliei lui

${ }^{18}$ Daniel, Patriarhul Bisericii Ortodoxe Române, Ştiința mântuirii, București, Editura Basilica, 2014, pp. 109-110.

19 Vezi Mihai Himcinschi, Biserica in societate, Alba Iulia, Editura Reîntregirea, 2006, p. 84 ș.u.. 
Hristos şi a credinței în El, ceea ce înseamnă că această comunitate devine lucrătoare prin iubire şi slujire a aproapelui.

\section{Bibliografie}

1. Arhieraticon, Bucureşti, Editura Institutului Biblic şi de Misiune al Bisericii Ortodoxe (în continuare, EIBMBOR), 1993.

2. Braniște, Ene, Liturgica Generală, București, EIBMBOR, 1993.

3. Idem, Liturgica Specială, București, EIBMBOR, 1980.

4. Bel, Pr.Prof. Dr. Valer, Misiune, Parohie, Pastoratie, Cluj, Edit. Renaşterea, 2002.

5. Cabasila, Nicolae, Tâlcuirea Dumnezeieştii Liturghii şi Despre viața in Hristos, Bucureşti, Editura Arhiepiscopiei Bucureştilor, 1989.

6. Ciobotea, Mitropolitul Moldovei Daniel, Taina fratelui, în „Candela Moldovei", III, nr. 1-2, pp. 1-13.

7. Daniel, Patriarhul Bisericii Ortodoxe Române, Ştiinţa mântuirii, București, Editura Basilica, 2014.

8. Ioan Gură de Aur, Sfântul, Omilia 50 la Evanghelia după Matei, în PSB 23, București, EIBMBOR, 1994.

9. Ioan din Kronștadt, Liturghia - cerul pe pământ, Sibiu, Edit. Deisis, 2002.

10. Himcinschi, Mihai, Biserica in societate, Alba Iulia, Editura Reîntregirea, 2006.

11. Mettalinos, Gheorghios D., Parohia - Hristos in mijlocul nostru, Sibiu, Edit. Deisis, 2004.

12. Miloșevici, Nenad S., Dumnezeiasca Liturghie - centrul cultului în Ortodoxie, Sibiu, Editura Deisis, 2012.

13. Molitfelnic, București, EIBMBOR, 1998. 